\title{
Potential applications of radioprotective phytochemicals from marine algae
}

\author{
Jae-Young Oh, I. P. Shanura Fernando and You-Jin Jeon* \\ Department of Marine Life Science, Jeju National University, Jeju 63243, Korea
}

The use of ionizing radiation and radioactive elements is becoming increasingly popular with the rapid developments in nuclear technology, radiotherapy, and radio diagnostic methods. However, ionizing radiation can directly or indirectly cause life-threatening complications such as cancer, radiation burns, and impaired immunity. Environmental contamination with radioactive elements and the depletion of ozone layer also contribute to the increased levels of radiation exposure. Radioprotective natural products have particularly received attention for their potential usefulness in counteracting radiation-induced damage because of their reduced toxicity compared with most drugs currently in use. Moreover, radioprotective substances are used as ingredients in cosmetic formulations in order to provide protection against ultraviolet radiation. Over the past few decades, the exploration of marine algae has revealed the presence of radioprotective phytochemicals, such as phlorotannins, polysaccharides, carotenoids and other compounds. With their promising radioprotective effects, marine algae could be a future source for discovering potential radioprotective substances for development as useful in therapeutics.

Key Words: ionizing radiation; marine algae; phlorotannins; radioprotectors; sulfated polysaccharides

\section{INTRODUCTION}

Ionizing radiation is an electromagnetic wave or a highenergy particle that can penetrate matter, producing ions following its collapse while traveling in its path (Varanda and Tavares 1998). It is potentially lethal and mutagenic and can induce chemical alterations in body tissues, which could result in a series of harmful effects. However, ionizing radiation also has beneficial characteristics that could be helpful in treating human diseases. The development of radioprotective substances has attracted an increasing interest because of their potential use in radiotherapy, counteracting occupational radiation hazards, space exploration, and in research. However, exposure to ionizing radiation can cause a range of detrimental ef- fects from radiation burns to radiation-induced cancer or rapid fatality (Christensen et al. 2014). Screening natural sources for radioprotective phytochemicals can lead to the identification of novel bioactive molecules, which could be further, chemically modified for synthesizing potentially useful molecular entities.

Considering its beneficial and detrimental effects, ionizing radiation, could be considered a double-edged sword. Ionizing radiation includes electromagnetic radiation such as far ultraviolet light, $\mathrm{X}$-rays, gamma rays,ionizing subatomic particles such as $\alpha$ and $\beta$ particles, and high energy neutrons and positrons resulting from radioactive decay and cosmic ray showers (Wood-
(9) $\$$ This is an Open Access article distributed under the terms of the Creative Commons Attribution Non-Commercial License (http://creativecommons.org/licenses/by-nc/3.0/) which permits unrestricted non-commercial use, distribution, and reproduction in any medium, provided the original work is properly cited.
Received October 12, 2016, Accepted December 1, 2016

* Corresponding Author

E-mail: youjin2014@gmail.com

Tel: +82-64-754-3475, Fax: +82-64-756-3493 


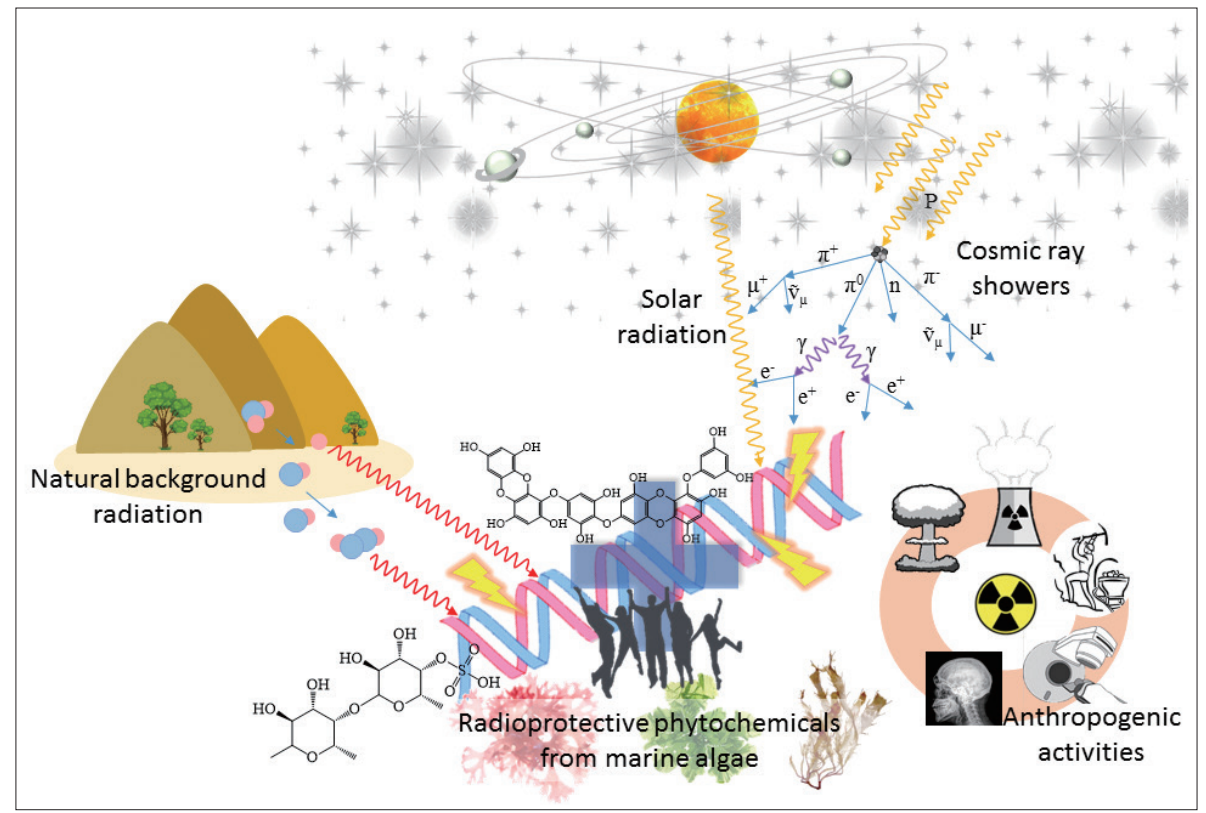

Fig. 1. Sources and detrimental effects of ionization radiation and the significance of phytochemicals to counteract them. lonizing radiation from cosmic ray showers, natural or background radiation and caused by anthropogenic agents could directly or indirectly damage essential biomolecules altering their structures consequently causing detrimental health effects. Radioprotective phytochemicals from marine algae could help in counteracting the effects caused by ionizing radiation.

side and Kocurek 1997). Organisms are constantly exposed to ionizing radiation because radioactive materials are dispersed throughout the Earth, which is constantly bombarded by solar radiation and cosmic ray showers. Exposure to ionizing radiation triggers the production of reactive oxygen species (ROS) that mainly include hydroxyl, superoxide radicals, hydrogen peroxide and singlet oxygen (Ewing and Jones 1987). These ROS react with cellular macromolecules including DNA, RNA, membrane lipids, and proteins, leading to cellular dysfunction and DNA damage, resulting in chromosomal abnormalities and mutations that cause cancers. Nonetheless, ionizing radiation has been used in radiotherapy as the most common treatment for human cancer (Nair et al. 2001). In addition significant attention has been focused on the adverse effects of UV exposure that results in skin damage, tumors, and photoaging (Ichihashi et al. 2003).

Investigations on strategies for protecting human tissues from ionizing radiation were initiated during the early nineteenth century after the discovery of X-rays. Soon after World War II, intensive efforts were focused on identifying radioprotective compounds. As a result, free radical-scavenging antioxidants were found to be effective radioprotectors (Prasad 1995). The rapid advances in $\mathrm{X}$-ray diagnostic techniques, radiotherapy, and nuclear technology has increased the implementation of strategies to discover effective radioprotectors. Currently there is a growing concern about the harmful effects of radio frequency radiation used in mobile telecommunication devices (Mohamed et al. 2014). Considering the tremendous importance of identifying substances with reduced toxicity, studies centered on radioprotectors from natural origin have attracted the attention of researchers. Secondary metabolites of marine algae exhibit different structural and functional properties from those of their terrestrial counterparts mainly due to the evolutionary antiquity of these organisms (Elyakov and Stonik 2003, Fernando et al. 2016b). The sources and detrimental effects of ionization radiation and the significance of the use of phytochemicals to counteract them are shown in Figure 1. Although terrestrial organisms have been widely studied as possible sources of radioprotective natural products, marine fauna and flora are still an under-explored natural resource. Many of these compounds that possess radioprotective activities are also antioxidants that provide complementary health benefits (Fernando et al. 2016a). This review briefly summarizes the current state of knowledge about the radioprotective natural products identified from marine algae. 


\section{IONIZING RADIATION-INDUCED REACTIVE OXYGEN SPECIES GENERATION AND ITS DETRI- MENTAL EFFECTS}

On the basis of the source, ionizing radiation can be classified as being from natural sources including natural radioactive materials as well as, solar and cosmic radiation, or synthetic sources including X-ray tubes, nuclear reactors, particle accelerators, and nuclear warfare (United Nations Scientific Committee on the Effects of Atomic Radiation 2000). UV radiation emitted by the sun is composed of relatively low energy photons that can interact with organic molecules to form radicals that react with molecular oxygen, leading to the production of peroxyl radicals. Alternatively, electron transfer from organic radicals to molecular oxygen results in high-energy molecular oxygen in its "triplet" ground state that generates singlet oxygen species by pairing their electronic spins. Consequently, this action form ROS such as peroxides, hydroperoxides or endoperoxides (Riley 1994). In contrast X-rays and $\gamma$-rays of the electromagnetic spectrum consist of high-energy photons that can eject electrons from atoms causing molecular ionization. Similarly, high-energy particles such as $\alpha$ and $\beta$ rays could cause molecular ionization, which generates hydroxyl peroxyl and alkoxyl radicals with superoxide hydrogen peroxide and oxides of nitrogen (Riley 1994, Gutteridge 1995). Water, an essential constituent of all living organisms has been found to undergo radiolysis following irradiation to produce several ROS (Pastina and LaVerne 2001). These effects could be direct or indirect, whereas ROS produced from direct irradiation propagate further to form additional ROS. The pattern of ROS formation is a function of energy deposition which correlates with the linear energy transfer value of the particle involved and depends on the colliding molecules in the biological system (Persaud et al. 2005).

Investigations of chemicals that with possible radioprotective effects commenced soon after the World War II (after project "Manhattan") to safeguard humans from the harmful effects of radiation caused by nuclear warheads. Initially, amino acids that can produce thiols such as cysteine and several others were investigated for radioprotective effects. However, the use of certain thiols was limited because they can cause potentially toxic effects. Since then, several botanicals have been identified to be effective against radiation-induced effects (Jagetia 2007). In addition to natural compounds, synthetically derived chemicals have been found to be effective against radiation damage. Amifostine is an example of a thiophos- phate prodrug currently used in therapeutics that convert into an active cytoprotective thiol metabolite (Maurya et al. 2006). The radioprotective efficacy of substances is further related to their biofunctional properties such as antioxidant, radical scavenging, anti-inflammatory, and anti-stress activities. The evaluation of properties such as radical scavenging, lipid peroxidation, apoptosis, DNA damage, and levels of glutathione (an antioxidant hormone) and enzymes such as catalase and glutathione peroxidase could provide useful information about the radioprotective activity of substances. Nevertheless, the best strategy for evaluating the radioprotective effect of pharmacological agents could be the determination of their recovery and regeneration of the gastrointestinal epithelium and hemopoietic progenitor cells in the bone marrow, which is the most radiosensitive organ essential for sustaining life.

Marine algae are considered a rich source of biofunctional metabolites with potential health benefits that have been utilized in manufacturing an array of consumer products (Barrow and Shahidi 2007). Algae metabolites have been widely explored for radioprotective effects and among these natural products, polysaccharides and polyphenolic compounds have occupied the leading position with a considerable number of publications. Although there are literature reports about radioprotective peptides from other natural sources, little is known about the radioprotective effects of peptides and amino acids from algae (Dittmann et al. 2001). This current review discusses the beneficial and detrimental effects of ionizing radiation and highlights the radio protective effects of algae derived phytochemicals against ionizing radiation.

\section{RADIOPROTECTIVE EFFECTS OF NATURAL PRODUCTS DERIVED FROM MARINE ALGAE}

\section{Radioprotective effects of polysaccharides de- rived from marine algae}

Polysaccharides from marine algae are widely used in food, cosmetics and pharmaceutical products and have been explored widely for their antioxidant, anticoagulant, radioprotective, anticancer, antiviral, and antiallergic properties (Ngo and Kim 2013, Kandasamy et al. 2015). Much of these functional molecules have been found to consist of sulfate groups attached to the hydroxyl oxygen atoms of the in its monosaccharide backbone and are known as sulfated polysaccharides (SPs). Brown algae (Phaeophyta) contain SPs, which include fucoidan, 
sulfated alginates, sulfated galactans, sargassan, ascophyllan, and glucuronoxylofucan. Red algae contain SPs that include galactans (agar), carrageenans, and sulfated mannans. Green algae contain sulfated heteropolysaccharides consisting of galactose, xylose, glucose, arabinose, glucuronic acid, and mannose (Ngo and Kim 2013, Usov and Zelinsky 2013). SPs from marine algae have received considerable attention owing to their nontoxic nature compared with that of other natural or commercial radioprotective agents. Polysaccharides have been found to interact with ionizing radiation by reacting with the ROS produced by the ionization of water and other molecules. The carrageenan present in red algae has been found to undergo structural changes including desulfation and acidification which increase the amount of reducing end groups following $\gamma$-ray irradiation (Abad et al. 2009). Chertkov et al. (1986) described the protective effects of carrageenan in mice against proton radiationinduced damage. Alginates have also been found to undergo structural changes (double bond formation in pyranose-ring) following $\gamma$-ray irradiation (Nagasawa et al. 2000). Fucoidan has been extensively investigated for its radioprotective effects by using in vivo experiments. Tawfik and Salama's report (2011) about the radioprotective effects of fucoidan in Sprague-Dawley rats exposed to $5 \mathrm{~Gy} \gamma$-rays including the effective recovery of the detrimental conditions, which ameliorated the radiation effects. Nesterenko et al. (2009) reported that foods containing alginate along with antioxidant vitamins were administered to the individuals who were exposed to the radiation released during the Chernobyl nuclear disaster to remediate the damage. Alginates do not undergo

Table 1. Radioprotective polysaccharides isolated from marine algae

\begin{tabular}{|c|c|c|}
\hline Entity & Biological significance & Reference \\
\hline $\begin{array}{l}\text { A sulfated polysaccharide purified } \\
\text { from Ecklonia cava }\end{array}$ & $\begin{array}{l}\text { Recovery of small intestinal stem cells in mice from } \gamma \text {-ray- } \\
\text { induced radiation damage }\end{array}$ & Oh et al. (2013) \\
\hline $\begin{array}{l}\text { A sulfated polysaccharide contain- } \\
\text { ing higher amounts of rhamnose }\end{array}$ & $\begin{array}{l}\text { Recovery of leukocyte, thrombocyte and erythrocyte count } \\
\text { in X-ray irradiated BALB/c mice }\end{array}$ & Mao et al. (2005) \\
\hline $\begin{array}{l}\text { A polysaccharide isolated from } \\
\text { Spirulina platensis }\end{array}$ & $\begin{array}{l}\text { Radioprotective effects against } \gamma \text {-ray-induced bone marrow } \\
\text { damage in mice and dogs }\end{array}$ & Zhang et al. (2001) \\
\hline $\begin{array}{l}\text { Fucoidan purified from Fucus ve- } \\
\text { siculosus and Laminaria japonica }\end{array}$ & $\begin{array}{l}\text { Radioprotective effects on human monoblastic leukemia } \\
\text { cell line U937 and recovery of blood cell counts in } \gamma \text {-ray } \\
\text { irradiated BALB/c mice }\end{array}$ & Rhee and Lee (2011) \\
\hline $\begin{array}{l}\text { Polysaccharides isolated from fer- } \\
\text { mented E. cava using Lactobacil- } \\
\text { lus brevis }\end{array}$ & $\begin{array}{l}\text { Enhanced survival, proliferation and reduced DNA damage } \\
\text { in } \gamma \text {-ray-irradiated murine splenocytes }\end{array}$ & Lee et al. (2013) \\
\hline $\begin{array}{l}\text { Commercial fucoidan purified from } \\
\text { F. vesiculosus }\end{array}$ & $\begin{array}{l}\text { Radioprotective effects on bone marrow cells and endog- } \\
\text { enous spleen cell colonies in mice exposed to total body } \\
\text { irradiation }\end{array}$ & Lee et al. (2008) \\
\hline Polysaccharides from L. japonica & $\begin{array}{l}\text { Radioprotective effects on mouse male reproductive system } \\
\text { and recovery of mating dysfunctionalities induced by } \\
\text { mini-dose } \gamma \text {-ray-irradiation }\end{array}$ & Qiong et al. (2011) \\
\hline $\begin{array}{l}\text { Different molecule weight polysac- } \\
\text { charides from Ulva pertusa }\end{array}$ & $\begin{array}{l}\text { Anti-radiation activities in mice exposed to electron beam } \\
\text { radiation }\end{array}$ & Shi et al. (2013) \\
\hline $\begin{array}{l}\text { Fucoidan purified from F. vesiculo- } \\
\text { sus }\end{array}$ & $\begin{array}{l}\text { Increasing the cell viability of } \gamma \text {-ray irradiated bone marrow } \\
\text { cells and stimulation of antigen-presenting functions in } \\
\text { dendritic cells }\end{array}$ & Byon et al. (2008) \\
\hline $\begin{array}{l}\text { A high rhamnose-containing } \\
\text { sulfated polysaccharide purified } \\
\text { from the green alga Monostroma } \\
\text { angicava }\end{array}$ & $\begin{array}{l}\text { Recovery of leukocytes, thrombocytes and erythrocytes in } \\
\text { BALB/c mice exposed to whole-body X-ray irradiation }\end{array}$ & Mao et al. (2005) \\
\hline $\begin{array}{l}\text { Low molecular weight polysaccha- } \\
\text { rides from } U \text {. pertusa }\end{array}$ & Radioprotective effects on mouse bone marrow cells & Shi et al. (2013) \\
\hline $\begin{array}{l}\text { Fucoidan purified from F. vesiculo- } \\
\text { sus and L. japonica }\end{array}$ & $\begin{array}{l}\text { Radioprotective effects on human foreskin fibroblast cell } \\
\text { line HS68 }\end{array}$ & Lee et al. (2009) \\
\hline $\begin{array}{l}\text { Translam-beta-1,3; 1,6-glucan, } \\
\text { extracted from Laminaria }\end{array}$ & $\begin{array}{l}\text { Reduction of Escherichia coli growth in spleen, increase the } \\
\text { activity of peritoneal macrophages in irradiated mice fed } \\
\text { with Translam-beta-1,3; 1,6-glucan }\end{array}$ & Kuznetsova et al. (1994) \\
\hline
\end{tabular}


metabolic degradation and are not absorbed by the body and therefore, do not possess any undesirable health risks (Höllriegl et al. 2004). Table 1 presents a list of radioprotective polysaccharides isolated from marine algae with their respective biological significance.

\section{Radioprotective effects of polyphenolic com- pounds derived from marine algae}

Polyphenolic compounds isolated from marine algae are well known for their diverse biological activities including antioxidant, radioprotective, anticancer, antiinflammatory, antidiabetic, and antihypertensive (Kang et al. 2014, 2015). These compounds are biosynthesized through the acetate-malonate pathway and share a phenol group as their common structural feature (Stein et al. 1973). A bewildering number of polyphenolic compounds with a perplexing structural diversity have been isolated from marine algae. These can be categorized into phenolic acids, phlorotannins, lignins, lignans, stilbenes, flavonoids, halogenated phenolic compounds, and other classes (Martone et al. 2009, Li et al. 2011). Among the polyphenols, phlorotannins have received considerable attention for their interesting antioxidant activities and other biofunctionalities (Eom et al. 2015, Lee et al. 2015b). These compounds have been isolated from brown algae and can protect cells from radiation-induced damage and oxidative stress (Shin et al. 2014, Lee et al. 2015a). Several studies have highlighted the remarkable radioprotective effects of phlorotannins isolated from Ecklonia cava and
Ishige okamurae (Park et al. 2008, Heo et al. 2009). Flavonoids are another prominent class of polyphenolic compounds found in algae and a number of studies indicate that flavonoids isolated from land plants have radioprotective effects. However, there is a dearth of information on the radioprotective effects of flavonoids isolated from algae. Flavonoids, such as luteolin, hesperetin, quercetin, rutin, and kaempferol, and flavone glycosides, such as orientin and vicenin, isolated from terrestrial plants have shown potential radioprotective effects (Venkatachalam and Chattopadhyay 2005). Of these flavonoids luteolin, quercetin, orientin, and vicenin have been reported in marine algae (Markham and Porter 1969, Fernando et al. 2016a). The evaluation of radioprotective effects of marine algal flavonoids could reveal interesting activities. Moreover, the conjugation of polyphenolic entities with other molecules could modify their functionalities. Salgado et al. (2007) reported that the interaction of polyphenolic compounds with alginates could produce long lasting UV protective effects. about the radioprotective effects of polyphenolic compounds derived from marine algae are summarized in Table 2, while the structures of these phytochemicals are represented in Fig. 2A-E.

\section{Radioprotective effects of carotenoids derived from marine algae}

Carotenoids are naturally occurring tetraterpenoids with a large structural diversity. These compounds are responsible for the bright red, yellow, orange and brown

Table 2. Radioprotective phenolic compounds isolated from marine algae

\begin{tabular}{|c|c|c|}
\hline Phenolic compound & Biological significance & Reference \\
\hline Dieckol from Ecklonia cava & Protective effects against UV-B induced cell damage & Heo et al. (2009) \\
\hline Eckol isolated from E. cava & $\begin{array}{l}\text { Radioprotective effects against gamma-ray-induced damage in } \\
\text { irradiated mice and the encasement of immune cell prolifera- } \\
\text { tion }\end{array}$ & Park et al. (2008) \\
\hline $\begin{array}{l}\text { Phloroglucinol and eckol isolated } \\
\text { from E. cava }\end{array}$ & $\begin{array}{l}\text { Antioxidant activity and protective effects on intestinal stem } \\
\text { cells against } \gamma \text {-irradiation-induced oxidative damage }\end{array}$ & Moon et al. (2008) \\
\hline Phloroglucinol purified from E. cava & $\begin{array}{l}\text { Protection against radiation-induced oxidative stress and apop- } \\
\text { tosis in blood lymphocytes and splenocytes }\end{array}$ & Park et al. (2011) \\
\hline Phloroglucinol from E. cava & $\begin{array}{l}\text { Protective effects against } \gamma \text {-iradiation-induced oxidative stress } \\
\text { and cell damage in Chinese hamster lung fibroblasts (V79-4) } \\
\text { cells and in female BALB/c mice }\end{array}$ & Kang et al. (2010) \\
\hline Triphlorethol-A purified from E. cava & $\begin{array}{l}\text { Cytoprotective effects against } \gamma \text {-ray irradiation- induced oxida- } \\
\text { tive stress and DNA damage. Inhibition of apoptosis through } \\
\text { downregulating Bax and Bcl-2 expression levels, while upregu- } \\
\text { lating caspase-3 }\end{array}$ & Kang et al. (2006) \\
\hline $\begin{array}{l}\text { Diphlorethohydroxycarmalol iso- } \\
\text { lated from Ishige okamurae }\end{array}$ & $\begin{array}{l}\text { Radioprotective effects against gamma-irradiation-induced } \\
\text { damage in irradiated Chinese hamster lung fibroblast (V79-4) } \\
\text { cells and mice }\end{array}$ & Ahn et al. (2011) \\
\hline
\end{tabular}




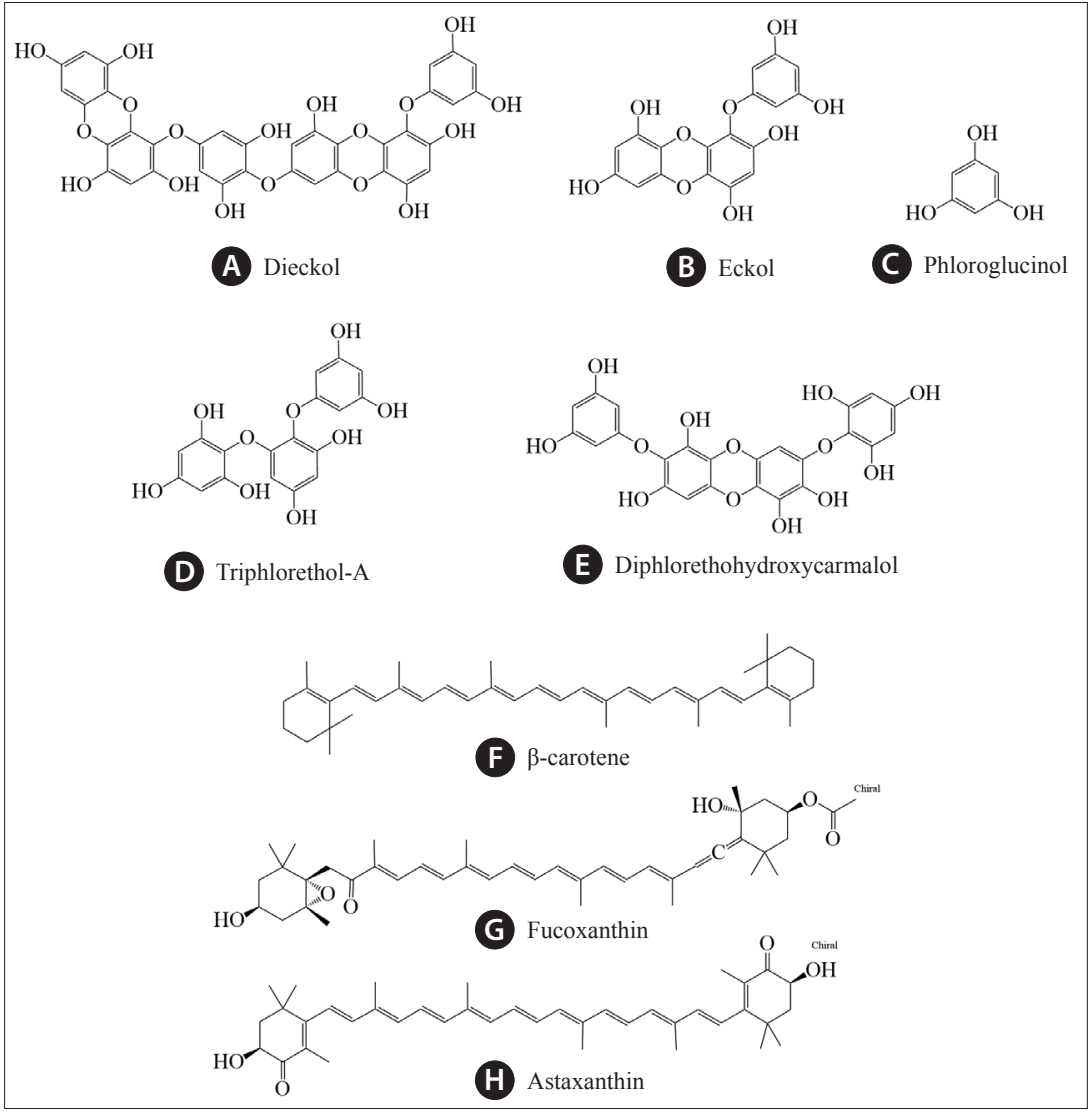

Fig. 2. (A-H) Structures of radioprotective phytochemicals isolated from marine algae.

colors in plants, algae, fungi, and in bacteria. Numerous different types of carotenoids have been reported in marine algae, and many of them possess antioxidant and radical scavenging activities. Moreover, radioprotective, anticancer and immune-enhancing activities have also been identified in carotenoids (Christaki et al. 2013). The carotenoids isolated from marine algae have been presented in Table 3 and their corresponding structures are shown in Fig. 2F-H.

\section{Other radioactive phytochemicals from marine algae}

Proteins and peptides from terrestrial organisms have been extensively studied for radioprotective effects. however, those from marine algae remain underexplored. Biliprotein C-phycocyanin isolated from the blue-green algae Arthrospira fusiformis was found to selectively stimulate the lymphocyte antioxidant defense mecha-

Table 3. Radioprotective carotenoids isolated from marine algae

\begin{tabular}{ccc}
\hline \multicolumn{1}{c}{ Carotenoid } & Biological significance & Reference \\
\hline $\begin{array}{c}\text { An isomeric mixture of } \beta \text {-carotene } \\
\text { purified from Dunaliella bardawil }\end{array}$ & $\begin{array}{c}\text { Decrease in the serum levels of oxidized conjugated dienes } \\
\text { in children exposed to radiation from Chernobyl accident } \\
\text { by reducing damage due to lipid peroxidation }\end{array}$ & Ben-Amotz et al. (1998) \\
$\begin{array}{c}\text { Fucoxanthin isolated from Sargas- } \\
\text { sum siliquastrum }\end{array}$ & $\begin{array}{l}\text { Protective effects against UV-B-induced cell damage in hu- } \\
\text { man fibroblast cells }\end{array}$ & Heo and Jeon (2009) \\
$\begin{array}{c}\text { An algae extract highly abundant } \\
\text { in astaxanthin }\end{array}$ & $\begin{array}{c}\text { Protective effects against UV-A-induced DNA damage in } \\
\text { human melanocytes (HEMAc), human skin fibroblasts } \\
\text { (1BR-3) and human intestinal CaCo-2 cells }\end{array}$ & Lyons and O'Brien (2002) \\
& &
\end{tabular}


nisms in human subjects occupationally exposed to low doses of $\gamma$-radiation compared to that in an unexposed control group (Ivanova et al. 2010). This stimulation was induced by the activation of antioxidant defense mechanisms through manganese superoxide dismutase, catalase, and glutathione-S-transferase (Ivanova et al. 2010). An extract, prepared from Phaeodactylum tricornutum was found to increase proteasome peptidase activities, which is responsible for degradating oxidized proteins of human keratinocytes exposed to UV-A and UV-B irradiation (Bulteau et al. 2006).

The polyphyletic evolutionary trends of the major algal groups have led to the diverse dispersion of, some secondary metabolites (Usov and Zelinsky 2013). The oral administration of Chlorella vulgaris E-25 have shown recovery effects on endogenous spleen cells and bone marrow of irradiated mice (Singh et al. 1995). Spirulina, the green microalgae has gained immense attention for its nutraceutical value and biofunctional properties (Belay et al. 1993). An ethanol extract derived from Bonnemaisonia hamifera has shown protective effects against UV-B-induced cell damage and ROS production in human $\mathrm{HaCaT}$ keratinocytes (Piao et al. 2012). The ethanol precipitate of the hot water extract from Spirulina platensis has shown protective effects on $\gamma$-ray irradiated mouse bone marrow cells (Qishen et al. 1989). The hexane and ethyl acetate fractions of the methanol extract of Callophyllis japonica have shown radioprotective activity against blood progenitor cells in gamma-irradiated BALB/c mice (Kim et al. 2008) while the ethyl acetate extract of this algae showed gastroprotective effects by enhancing the survival of jejunum crypts (Shin et al. 2010). The methanol extract of Polyopes lancifolia has shown protective effects against radiation-induced oxidative stress in mice subjected to total-body $\gamma$-irradiation based on histological studies (Jeong et al. 2011).

\section{COMPLEXATION OF MARINE ALGAE DERIVED NATURAL PRODUCTS THAT COULD REDUCE BIOAVAILABILITY OF RADIONUCLIDES}

The contamination of marine habitats by the disposal of radioactive waste has become a major worldwide issue of concern. These radioactive elements could directly or indirectly induce radiation damage in organisms follow- ing exposure. In adition to the external body irradiation, internal exposure could directly damage tissues, causing serious carcinogenic effects. Therefore, the removal of these environmental contaminants and the reduction of the bioavailability of radioactive elements could protect organisms from indirect damage associated with radiation exposure. This could be achieved by complexing or chelating metal ions using a natural product ligand, which in this case, could be expected to reduce the ion bioavailability. The brown alga, Undaria pinnatifida or the sea mustard has been found to take up the radioactive strontium-90 isotope from seawater (Yoo et al. 1982). The unicellular green alga Chlamydomonas reinhardtii has been reported to reduce the uranium content of water (Fortin et al. 2004). Autoradiographic studies have revealed the accumulation of the radioactive ${ }^{95} \mathrm{Tc}$ isotope in the brown algae Fucus spiralis, Ascophyllum nodosum and F. vesiculosus and the red algae Porphyra umbilicalis (Bonotto et al. 1988). Sargassum filipendula, Padina vickersiae, and Acanthophora spicifera which inhabit the southern coastal areas of Rio de Janeiro, Brazil, have shown the accumulation of ${ }^{137} \mathrm{Cs},{ }^{60} \mathrm{Co}$, and ${ }^{125} \mathrm{I}$ radionuclides from contaminated water (Guimarães and Penna-Franca 1985). The aforementioned bioaccumulation processes could occur because of the chelating agents present in algae which mainly include polysaccharides with carboxylic acid functional groups such as alginic acid, different types of carrageenans, xanthan and dextran (Quigley et al. 2002). Further, an effective complexation of radioactive ${ }^{234} \mathrm{Th}$ and other radionuclides $(\mathrm{Pu}, \mathrm{Am}$, and $\mathrm{Po})$ but to a lesser degree than other radionuclides, has been observed by acid polysaccharides from marine organic matter (Quigley et al. 2002). According to Höllriegl et al. (2004) consumption of sodium alginate could reduce the gastrointestinal absorption of ${ }^{90} \mathrm{Sr}$ in humans by its efficient chelating properties. The uptake efficiency of radionuclides from marine algae in the field surpasses that expected in laboratory studies (McCartney and Rajendran 1997). Therefore, these algae could be useful as biomarker for monitoring radionuclide contamination in water. Algae could play an important role in the transfer of heavy metals and radionuclides through food chains. It would be useful to assess the heavy metal and radionuclide content of algae material, especially samples collected from their natural habitats before consumption to ensure the safety. 


\section{POTENTIAL APPLICATIONS OF RADIOPROTEC- TIVE SUBSTANCES DERIVED FROM MARINE ALGAE}

\section{Potential radiotheraputic uses of radioprotec- tive phytochemicals from marine algae}

Radiotherapy and radio diagnostic techniques are currently a common method for treating cancers and identifying anatomical alterations. The success of these methods depends on two factors including increasing the damage to cancer cells while reducing the damaging effects on the surrounding normal cells. Radiation cannot differentiate between cancer and surrounding normal cells. The discovery of radioprotective agents that selectively protect normal cells from radiation has advanced these agents to an important position in oncological research. Among thousands of radioprotective agents discovered throughout history, natural products remain as the least toxic (Nair et al. 2001). Marine algae have been shown to contain a number of radioprotective phytochemicals that have the potential to be advanced into clinical trials. As described in previous sections, the major mechanism of action of these phytochemicals involves radical scavenging-antioxidant effect. In addition, they could exert immunomodulatory effects and boost the antioxidant defense mechanisms in the body.

\section{Potential cosmeceutical uses of radioprotective phytochemicals from marine algae as}

Cosmeceuticals can be described as cosmetic products that exert pharmacological and therapeutic benefits rather than excreting just a single functionality. A number of synthetic ingredients are used in cosmetic formulations to achieve desirable functionalities. However, most of these synthetic chemicals cause detrimental side effects with prolonged use. Dermatological studies suggest that the use of natural bioactive ingredients in the preparation of cosmeceuticals could limit the detrimental effects and provide beneficial functionalities (Wijesinghe and Jeon 2012). Skin care cosmeceuticals are the most renowned cosmetic products. Exposure of the skin to ionizing radiation increases the generation of free radicals and ROS that cause an array of symptoms including erythema, tanning and local or systemic immunosuppression (Matsumura and Ananthaswamy 2004). Numorous natural products present in algae have been proven to produce effective radical scavenging antioxidant properties without cytotoxicities effects. A number of studies have shown the UV protective effects of algae metabolites such as dieckol, fucoxanthin, astaxanthin and algae extracts that contain numorous different bioactive substances, which supports their use in cosmeceutical formulations (Lyons and O'Brien 2002, Heo and Jeon 2009, Heo et al. 2009). The direct incorporation of algae extracts or partially purified sub-fractions in cosmeceuticals could provide additional bio functionalities in a cost-effective manner. Despite the proven usefulness of multi bioactive compound formulations, single compounds such as dieckol isolated from $E$. cava have also been shown to be effective both as whitening and UV-B protective agents (Heo et al. 2009).

\section{CONCLUSION}

The discovery of radioprotectors has received considerable attention owing to rapid advances in nuclear technology, radiotherapy, radio diagnostic methods, telecommunication technology and research centered on the use of radioactive elements. Moreover, the depletion of the ozone layer and anthropogenic activities could contribute to the contamination of the environment with radioactive elements, which could eventually have a considerable impact on the radiation exposure level. Marine algae have been extensively studied over the past few decades for the identification of bioactive natural products (Heo et al. 2006). Radioprotective substances, including phlorotannins, polysaccharides and carotenoids have been identified in marine algae. Most of these phytochemicals possess multiple functionalities centered on their anti-oxidant effects. The comparably low toxicity of these natural products compared to that of synthetic radioprotectors could further extend widen the perspective of the oncological research into these substances. In addition, radioprotective algae extracts or their purified phytochemicals could be used as ingredients for producing cosmeceuticals, which could offer protection against UV and other harmful radiation. However, studies on the radioprotective effects of algae phytochemicals have not been as extensive as studies on their other biological activities. Finally the discovery of radioprotective substances from marine algae could hold the key to unraveling potential radioprotective functionality of these and other similar substances. 


\section{REFERENCES}

Abad, L. V., Kudo, H., Saiki, S., Nagasawa, N., Tamada, M., Katsumura, Y., Aranilla, C. T., Relleve, L. S. \& De La Rosa, A. M. 2009. Radiation degradation studies of carrageenans. Carbohydr. Polym. 78:100-106.

Ahn, M., Moon, C., Yang, W., Ko, E. -J., Hyun, J. W., Joo, H. G., Jee, Y., Lee, N. H., Park, J. W., Ko, R. K., Kim, G. O. \& Shin, T. 2011. Diphlorethohydroxycarmalol, isolated from the brown algae Ishige okamurae, protects against radiation-induced cell damage in mice. Food Chem. Toxicol. 49:864-870.

Barrow, C. \& Shahidi, F. 2007. Marine nutraceuticals and functional foods. CRC Press, Boca Raton, FL, 512 pp.

Belay, A., Ota, Y., Miyakawa, K. \& Shimamatsu, H. 1993. Current knowledge on potential health benefits of Spirulina. J. Appl. Phycol. 5:235-241.

Ben-Amotz, A., Yatziv, S., Sela, M., Greenberg, S., Rachmilevich, B., Shwarzman, M. \& Weshler, Z. 1998. Effect of natural $\beta$-carotene supplementation in children exposed to radiation from the Chernobyl accident. Radiat. Environ. Biophys. 37:187-193.

Bonotto, S., Robbrecht, V., Nuyts, G., Cogneau, M. \& van der Ben, D. 1988. Uptake of technetium by marine algae: autoradiographic localization. Mar. Pollut. Bull. 19:61-65.

Bulteau, A. -L., Moreau, M., Saunois, A., Nizard, C. \& Friguet, B. 2006. Algae extract-mediated stimulation and protection of proteasome activity within human keratinocytes exposed to UVA and UVB irradiation. Antioxid. Redox Signal. 8:136-143.

Byon, Y. -Y., Kim, M. -H., Yoo, E. -S., Hwang, K. -K., Jee, Y., Shin, T. \& Joo, H. -G. 2008. Radioprotective effects of fucoidan on bone marrow cells: improvement of the cell survival and immunoreactivity. J. Vet. Sci. 9:359-365.

Chertkov, K. S., Gvozdeva, N. I., Fedorenko, B. S. \& Preobrazhenski1̌, Y. Y. 1986. Radioprotective and therapeutic efficacy of carrageenan during exposure to proton radiation. Kosm. Biol. Aviakosm. Med. 20:84-86.

Christaki, E., Bonos, E., Giannenas, I. \& Florou-Paneri, P. 2013. Functional properties of carotenoids originating from algae. J. Sci. Food Agric. 93:5-11.

Christensen, D. M., Iddins, C. J. \& Sugarman, S. L. 2014. Ionizing radiation injuries and illnesses. Emerg. Med. Clin. North Am. 32:245-265.

Dittmann, K. H., Gueven, N., Mayer, C. \& Rodemann, H. -P. 2001. Characterization of the amino acids essential for the photo- and radioprotective effects of a Bowman-Birk protease inhibitor-derived nonapeptide. Protein Eng. 14:157-160.

Elyakov, G. B. \& Stonik, V. A. 2003. Marine bioorganic chem- istry as the base of marine biotechnology. Russ. Chem. Bull. 52:1-19.

Eom, S.- H., Moon, S. -Y., Lee, D. -S., Kim, H. -J., Park, K., Lee, E. -W., Kim, T. H., Chung, Y. -H., Lee, M. -S. \& Kim, Y. -M. 2015. In vitro antiviral activity of dieckol and phlorofucofuroeckol-A isolated from edible brown alga Eisenia bicyclis against murine norovirus. Algae 30:241-246.

Ewing, D. \& Jones, S. R. 1987. Superoxide removal and radiation protection in bacteria. Arch. Biochem. Biophys. 254:53-62.

Fernando, I. P. S., Kim, M., Son, K. -T., Jeong, Y. \& Jeon, Y. -J. $2016 a$. Antioxidant activity of marine algal polyphenolic compounds: a mechanistic approach. J. Med. Food 19:615-628.

Fernando, I. P. S., Nah, J. -W. \& Jeon, Y. -J. 2016b. Potential anti-inflammatory natural products from marine algae. Environ. Toxicol. Pharmacol. 48:22-30.

Fortin, C., Dutels, L. \& Garnier-Laplace, J. 2004. Uranium complexation and uptake by a green alga in relation to chemical speciation: the importance of the free uranyl ion. Environ. Toxicol. Chem. 23:974-981.

Guimarães, J. R. D. \& Penna-Franca, E. $1985 .{ }^{137} \mathrm{Cs},{ }^{60} \mathrm{Co}$ and ${ }^{125}$ I bioaccumulation by seaweeds from the Angra dos Reis nuclear power plant region. Mar. Environ. Res. 16:77-93.

Gutteridge, J. M. 1995. Lipid peroxidation and antioxidants as biomarkers of tissue damage. Clin. Chem. 41:18191828.

Heo, S. -J., Cha, S. -H., Lee, K. -W. \& Jeon, Y. -J. 2006. Antioxidant activities of red algae from Jeju Island. Algae 21:149-156.

Heo, S. -J. \& Jeon, Y. -J. 2009. Protective effect of fucoxanthin isolated from Sargassum siliquastrum on UV-B induced cell damage. J. Photochem. Photobiol. B Biol. 95:101107.

Heo, S. -J., Ko, S. -C., Cha, S. -H., Kang, D. -H., Park, H. -S., Choi, Y. -U., Kim, D., Jung, W. -K. \& Jeon, Y. -J. 2009. Effect of phlorotannins isolated from Ecklonia cava on melanogenesis and their protective effect against photo-oxidative stress induced by UV-B radiation. Toxicol. In Vitro 23:1123-1130.

Höllriegl, V., Röhmuss, M., Oeh, U. \& Roth, P. 2004. Strontium biokinetics in humans: influence of alginate on the uptake of ingested strontium. Health Phys. 86:193-196.

Ichihashi, M., Ueda, M., Budiyanto, A., Bito, T., Oka, M., Fukunaga, M., Tsuru, K. \& Horikawa, T. 2003. UV-induced skin damage. Toxicology 189:21-39.

Ivanova, K. G., Stankova, K. G., Nikolov, V. N., Georgieva, R. T., Minkova, K. M., Gigova, L. G., Rupova, I. T. \& Boteva, R. N. 2010. The biliprotein C-phycocyanin modulates 
the early radiation response: a pilot study. Mutat. Res. 695:40-45.

Jagetia, G. C. 2007. Radioprotective potential of plants and herbs against the effects of ionizing radiation. J. Clin. Biochem. Nutr. 40:74-81.

Jeong, J., Yang, W., Ahn, M., Kim, K. C., Hyun, J. W., Kim, S. -H., Moon, C. \& Shin, T. 2011. Protective effect of the methanol extract of Polyopes lancifolia (Harvey) kawaguchi et wang against ionizing radiation-induced mouse gastrointestinal injury. Korean J. Vet. Res. 51:177-183.

Kandasamy, S., Khan, W., Kulshreshtha, G., Evans, F., Critchley, A. T., Fitton, J., Stringer, D. N., Gardiner, V. -A. \& Prithiviraj, B. 2015. The fucose containing polymer (FCP) rich fraction of Ascophyllum nodosum (L.) Le Jol. protects Caenorhabditis elegans against Pseudomonas aeruginosa by triggering innate immune signaling pathways and suppression of pathogen virulence factors. Algae 30:147-161.

Kang, K. A., Zhang, R., Chae, S., Lee, S. J., Kim, J., Kim, J., Jeong, J., Lee, J., Shin, T., Lee, N. H. \& Hyun, J. W. 2010. Phloroglucinol (1,3,5-trihydroxybenzene) protects against ionizing radiation-induced cell damage through inhibition of oxidative stress in vitro and in vivo. Chem.Biol. Interact. 185:215-226.

Kang, K. A., Zhang, R., Lee, K. H., Chae, S., Kim, B. J., Kwak, Y. S., Park, J. W., Lee, N. H. \& Hyun, J. W. 2006. Protective effect of triphlorethol-A from Ecklonia cava against ionizing radiation in vitro. J. Radiat. Res. 47:61-68.

Kang, M. -C., Kim, K. -N., Wijesinghe, W. A. J. P., Yang, X., Ahn, G. \& Jeon, Y. -J. 2014. Protective effect of polyphenol extracted from Ecklonia cava against ethanol induced oxidative damage in vitro and in zebrafish model. J. Funct. Foods 6:339-347.

Kang, N., Lee, J. -H., Lee, W., Ko, J. -Y., Kim, E. -A., Kim, J. -S., Heu, M. -S., Kim, G. H. \& Jeon, Y. -J. 2015. Gallic acid isolated from Spirogyra sp. improves cardiovascular disease through a vasorelaxant and antihypertensive effect. Environ. Toxicol. Pharmacol. 39:764-772.

Kim, J., Moon, C., Kim, H., Jeong, J., Lee, J., Kim, J., Hyun, J. W., Park, J. W., Moon, M. Y., Lee, N. H., Kim, S. H., Jee, Y. \& Shin, T. 2008. The radioprotective effects of the hexane and ethyl acetate extracts of Callophyllis japonica in mice that undergo whole body irradiation. J. Vet. Sci. 9:281-284.

Kuznetsova, T. A., Krylova, N. V., Besednova, N. N., Vasil'eva, V. N., Zviagintseva, T. N., Krashevskiı̌, S. \& Eliakova, L. A. 1994. The effect of translam on the natural resistance indices of the irradiated organism. Radiats. Biol. Radioecol. 34:236-239.

Lee, J., Kim, J., Moon, C., Kim, S. -H., Hyun, J. W., Park, J. W.
\& Shin, T. 2008. Radioprotective effects of fucoidan in mice treated with total body irradiation. Phytother. Res. 22:1677-1681.

Lee, J. -H., Ko, J. -Y., Oh, J. -Y., Kim, E. -A., Kim, C. -Y. \& Jeon, Y. -J. 2015a. Evaluation of phlorofucofuroeckol-A isolated from Ecklonia cava (Phaeophyta) on anti-lipid peroxidation in vitro and in vivo. Algae 30:313-323.

Lee, K. H., Bae, S. W., Cho, C. -H. \& Rhee, K. H. 2009. Fucoidan protects human skin fibroblast cell line HS68 against $\gamma$-radiation-induced damage. Open Nat. Prod. J. 2:38-41.

Lee, S. -H., Kang, S. -M., Sok, C. H., Hong, J. T., Oh, J. -Y. \& Jeon, Y. -J. 2015b. Cellular activities and docking studies of eckol isolated from Ecklonia cava (Laminariales, Phaeophyceae) as potential tyrosinase inhibitor. Algae 30:163-170.

Lee, W., Ahn, G., Lee, B. -J., Wijesinghe, W. A. J. P., Kim, D., Yang, H., Kim, Y. M., Park, S. J., Jee, Y. \& Jeon, Y. -J. 2013. Radio-protective effect of polysaccharides isolated from Lactobacillus brevis-fermented Ecklonia cava. Int. J. Biol. Macromol. 52:260-266.

Li, Y. -X., Wijesekara, I., Li, Y. \& Kim, S. -K. 2011. Phlorotannins as bioactive agents from brown algae. Process Biochem. 46:2219-2224.

Lyons, N. M. \& O'Brien, N. M. 2002. Modulatory effects of an algal extract containing astaxanthin on UVA-irradiated cells in culture. J. Dermatol. Sci. 30:73-84.

Mao, W., Li, Y., Wu, L., Wang, H., Zhang, Y., Zang, X. \& Zhang, H. 2005. Chemical characterization and radioprotective effect of polysaccharide from Monostroma angicava (Chlorophyta). J. Appl. Phycol. 17:349-354.

Markham, K. R. \& Porter, L. J. 1969. Flavonoids in the green algae (chlorophyta). Phytochemistry 8:1777-1781.

Martone, P. T., Estevez, J. M., Lu, F., Ruel, K., Denny, M. W., Somerville, C. \& Ralph, J. 2009. Discovery of lignin in seaweed reveals convergent evolution of cell-wall architecture. Curr. Biol. 19:169-175.

Matsumura, Y. \& Ananthaswamy, H. N. 2004. Toxic effects of ultraviolet radiation on the skin. Toxicol. Appl. Pharmacol. 195:298-308.

Maurya, D. K., Devasagayam, T. P. \& Nair, C. K. 2006. Some novel approaches for radioprotection and the beneficial effect of natural products. Indian J. Exp. Biol. 44:93-114.

McCartney, M. \& Rajendran, K. 1997. ${ }^{99}$ Tc in the Irish Sea. Recent trends. Radioprotection. Pt. 1. Inventories, behaviour and processes. In Germain, P., Guary, J. C., Guegueniat, P. \& Metivier, H. (Eds.) Radionuclides in the oceans. Cherbourg-Octeville, p. 359-364.

Mohamed, W. A., Ismail, S. A. \& El-Hakim, Y. M. A. 2014. Spirulina platensis ameliorative effect against GSM 900$\mathrm{MHz}$ cellular phone radiation-induced genotoxicity in 
male Sprague-Dawley rats. Comp. Clin. Path. 23:17191726.

Moon, C., Kim, S. -H., Kim, J. -C., Hyun, J. W., Lee, N. H., Park, J. W. \& Shin, T. 2008. Protective effect of phlorotannin components phloroglucinol and eckol on radiation-induced intestinal injury in mice. Phytother. Res. 22:238242.

Nagasawa, N., Mitomo, H., Yoshii, F. \& Kume, T. 2000. Radiation-induced degradation of sodium alginate. Polym. Degrad. Stab. 69:279-285.

Nair, C. K., Parida, D. K. \& Nomura, T. 2001. Radioprotectors in radiotherapy. J. Radiat. Res. 42:21-37.

Nesterenko, A. V., Nesterenko, V. B. \& Yablokov, A. V. 2009. Chapter IV. Radiation protection after the Chernobyl catastrophe. Ann. N. Y. Acad. Sci. 1181:287-327.

Ngo, D. -H. \& Kim, S. -K. 2013. Sulfated polysaccharides as bioactive agents from marine algae. Int. J. Biol. Macromol. 62:70-75.

Oh, H., Bing, S. J., Kim, A., Cho, J. \& Jee, Y. 2013. Radio-protective effect of sulfated polysaccharide purified from Ecklonia cava against small intestinal stem cells of $\gamma$-ray irradiated mice. J. Biomed. Res. 14:220-225.

Park, E., Ahn, G. -N., Lee, N. H., Kim, J. M., Yun, J. S., Hyun, J. W., Jeon, Y. -J., Wie, M. B., Lee, Y. J., Park, J. W. \& Jee, Y. 2008. Radioprotective properties of eckol against ionizing radiation in mice. FEBS Lett. 582:925-930.

Park, S. -J., Ahn, G., Lee, N. H., Park, J. W., Jeon, Y. -J. \& Jee, Y. 2011. Phloroglucinol (PG) purified from Ecklonia cava attenuates radiation-induced apoptosis in blood lymphocytes and splenocytes. Food Chem. Toxicol. 49:22362242.

Pastina, B. \& LaVerne, J. A. 2001. Effect of molecular hydrogen on hydrogen peroxide in water radiolysis. J. Phys. Chem. A 105:9316-9322.

Persaud, R., Zhou, H., Baker, S. E., Hei, T. K. \& Hall, E. J. 2005. Assessment of low linear energy transfer radiation-induced bystander mutagenesis in a three-dimensional culture model. Cancer Res. 65:9876-9882.

Piao, M. J., Hyun, Y. J., Cho, S. J., Kang, H. K., Yoo, E. S., Koh, Y. S., Lee, N. H., Ko, M. H. \& Hyun, J. W. 2012. An ethanol extract derived from Bonnemaisonia hamifera scavenges ultraviolet $B(U V B)$ radiation-induced reactive oxygen species and attenuates UVB-induced cell damage in human keratinocytes. Mar. Drugs 10:2826-2845.

Prasad, K. N. 1995. Handbook of radiobiology. CRC Press, Boca Raton, FL, 352 pp.

Qiong, L., Jun, L., Jun, Y., Yinzhu, Z., Xiaoyan, C. \& Mingliang, Y. 2011. The effect of Laminaria japonica polysaccharides on the recovery of the male rat reproductive system and mating function damaged by multiple mini- doses of ionizing radiations. Environ. Toxicol. Pharmacol. 31:286-294.

Qishen, P., Guo, B. J. \& Kolman, A. 1989. Radioprotective effect of extract from Spirulina platensis in mouse bone marrow cells studied by using the micronucleus test. Toxicol. Lett. 48:165-169.

Quigley, M. S., Santschi, P. H., Hung, C. -C., Guo, L. \& Honeyman, B. D. 2002. Importance of acid polysaccharides for ${ }^{234} \mathrm{Th}$ complexation to marine organic matter. Limnol. Oceanogr. 47:367-377.

Rhee, K. H. \& Lee, K. H. 2011. Protective effects of fucoidan against $\gamma$-radiation-induced damage of blood cells. Arch. Pharm. Res. 34:645-651.

Riley, P. A. 1994. Free radicals in biology: oxidative stress and the effects of ionizing radiation. Int. J. Radiat. Biol. 65:27-33.

Salgado, L. T., Tomazetto, R., Cinelli, L. P., Farina, M. \& Amado Filho, G. M. 2007. The influence of brown algae alginates on phenolic compounds capability of ultraviolet radiation absorption in vitro. Braz. J. Oceanogr. 55:145-154.

Shi, J., Cheng, C., Zhao, H., Jing, J., Gong, N. \& Lu, W. 2013. In vivo anti-radiation activities of the Ulva pertusa polysaccharides and polysaccharide-iron (III) complex. Int. J. Biol. Macromol. 60:341-346.

Shin, T., Ahn, M., Hyun, J. W., Kim, S. H. \& Moon, C. 2014. Antioxidant marine algae phlorotannins and radioprotection: a review of experimental evidence. Acta Histochem. 116:669-674.

Shin, T., Kim, H., Kim, J., Ahn, M., Moon, C., Hyun, J. W., Jee, Y., Lee, N. H. \& Park, J. W. 2010. A comparative study of radioprotection with Callophyllis japonica extract and amifostine against lethal whole body gamma irradiation in mice. Orient. Pharm. Exp. Med. 10:1-6.

Singh, S. P., Tiku, A. B. \& Kesavan, P. C. 1995. Post-exposure radioprotection by Chlorella vulgaris (E-25) in mice. Indian J. Exp. Biol. 33:612-615.

Stein, J. R., Hellebust, J. A. \& Craigie, J. S. 1973. Handbook of phycological methods: physiological and biochemical methods. Cambridge University Press, NY, 460 pp.

Tawfik, S. S. \& Salama, S. F. 2011. Preventive efficacy of fucoidan in rats exposed to $\gamma$-rays. J. Rad. Res. Appl. Sci. 4:233-244.

United Nations Scientific Committee on the Effects of Atomic Radiation. 2000. Sources and effects of ionizing radiation. Vol. 1. Sources . United Nations, NY, 654 pp.

Usov, A. I. \& Zelinsky, N. D. 2013. Chemical structures of algal polysaccharides. In Domínguez, H. (Ed.) Functional Ingredients from Algae for Foods and Nutraceuticals. Woodhead Publishing, Cambridge, pp. 23-86.

Varanda, E. A. \& Tavares, D. C. 1998. Radioprotection: mech- 
anisms and radioprotective agents including honeybee venom. J. Venom. Anim. Toxins 4:5-21.

Venkatachalam, S. R. \& Chattopadhyay, S. 2005. Natural radioprotective agents: an overview. Curr. Org. Chem. 9:389-404.

Wijesinghe, W. A. \& Jeon, Y. J. 2012. Exploiting biological activities of brown seaweed Ecklonia cava for potential industrial applications: a review. Int. J. Food Sci. Nutr. 63:225-235.
Woodside, G. \& Kocurek, D. 1997. Environmental, safety, and health engineering. John Wiley \& Sons, NY, $600 \mathrm{pp}$.

Yoo, B. -S., Lee, K. -J. \& Lee, S. -R. 1982. The uptake and loss of strontium-90 by the seaweed Undaria pinnatifida. J. Korean Nucl. Soc. 14:116-121.

Zhang, H. Q., Lin, A. P., Sun, Y. \& Deng, Y. M. 2001. Chemoand radio-protective effects of polysaccharide of Spirulina platensis on hemopoietic system of mice and dogs. Acta Pharmacol. Sin. 22:1121-1124. 